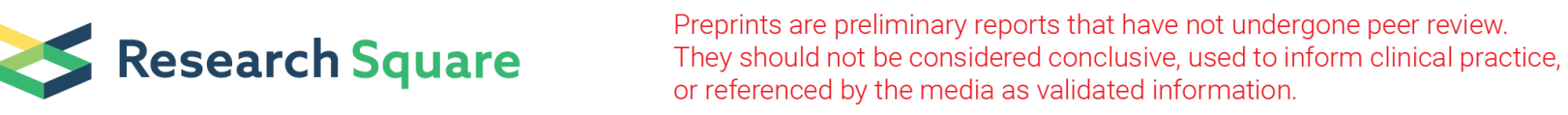

\title{
Daily water regime and sample sampling affect Blood and Urine parameter value change in healthy individuals
}

Snezana M Jovicic ( $\sim$ sneza90bg@hotmail.com )

Faculty of Biology, University of Belgrade

Research

Keywords: pre-analytical factors, water intake, sample sampling, blood biomarkers, urine biomarkers, healthy participants

Posted Date: March 6th, 2021

DOI: https://doi.org/10.21203/rs.3.rs-285890/v1

License: (c) (i) This work is licensed under a Creative Commons Attribution 4.0 International License.

Read Full License 


\section{Abstract}

Background: Blood and Urine biomarkers are indicators of the subject health status. Understanding the effect of pre-analytical factors is important for the data quality of bio-specimens. Water as a necessary element for the normal functioning of living beings and sampling frequency influences the homeostatic range of parameters. The study examines the effect of 9-days fluid intake and 2-time sampling on concentration changes of 7-Urine and 17-Blood variables.

Material and Method: SPSS software v23.0 applies to data processing. The group of 23 healthy subjects divide based on water intake and gender.

Results: A statistically significant difference $(\mathrm{p}<0.01)$ between $1^{\text {st }} / 2^{\text {nd }}$ sampling is confirmed for Freezing point depression, Sodium, Potassium, Creatinine Urea and Urate in Urine, Urea, Urate, Glucose, Hematocrit, Thrombocyte in Blood. The difference between water intake after $1^{\text {st }}$ sampling is confirmed $(p<0.01)$ for Freezing point depression, Sodium, Urate and $(p<0.05)$ for Potassium $(p<0.05)$, Chloride $(p<0.05)$, Creatinine $(p<0.05)$, Urate, Urea in Urine and Potassium $(p<0.01)$ and Chloride $(p<0.05)$ in Blood. Difference between gender exists for Urea $(\mathrm{p}<0.05)$ in Urine after $2^{\text {nd }}$ sampling and Urate $(P<0.01)$, Glucose $(p<0.01 / 0.05), \mathrm{Ht}(\mathrm{p}<0.01 / 0.05)$ after $1^{\text {st }}$ and $2^{\text {nd }}$ sampling and $\mathrm{MCHC}(\mathrm{p}<0.01)$ after $2^{\text {nd }}$ sampling in Blood samples.

Conclusion: Water intake increases Blood and Urine biomarker range after sampling.

\section{Background}

Homeostasis improves and maintains organism functional systems ${ }^{[1]}$. The nervous system regulates organism homeostasis in the inward environment by answering external stimulus ${ }^{[1]}$. The vegetative and autonomous nerve system regulate the function of the internal organs ${ }^{[1]}$. Enable the transport of hormones, vitamins, minerals and metabolism products through the Blood to distant tissues and organ systems ${ }^{[1]}$. Fluid in the inner environment contains nutritional material and oxygen, enabling the continuous renewal of molecules at the capillary ${ }^{[1]}$. Body fluid consists of cellular (in cells) and extracellular (in the Blood) water ${ }^{[2]}$. The Water amount in an organism depends on body mass, nutrition, age and gender ${ }^{[3]}$. The cellular fluid has a changeable lining and depends on tissue and organ ${ }^{[3]}$. Water has a protective (part of immunoglobulin, proteins) or regulator (par of hormones or enzymes) role in the body [2]. Water is an essential molecule for all living organisms and the most common compound on earth ${ }^{[2]}$. It is the ideal solvent and forms a useful environment for biochemical processes in a temperature range of $0-100^{\circ} \mathrm{C}^{[2]}$. Water forms hydrogen bonds with proteins, DNA and RNA molecules ${ }^{[2]}$. Water intake and hydration status are associated with disease prevalence, disease development and exercise performance ${ }^{[3]}$. 
The homeostatic mechanism precisely maintains Blood plasma and extracellular fluid content ${ }^{[3]}$. The Blood regulates cardiac function, integrity and elasticity of blood vessels, communicates with cells, tissues and organs ${ }^{[4]}$. Blood has a respiratory, nutritive, excretory, regulatory, transport and defensive role in an organism ${ }^{[4]}$. Water is quantitatively the most significant blood constituent. Blood contains fluid ( $45 \%$, plasma, serum) and constitutive (55\%, shaped elements like Erythrocytes, Leucocytes, Platelets) component ${ }^{[4]}$. The serum is plasma without fibrinogen. Plasma contains organic and inorganic matter, like water (92\%), proteins (7\%) and other ingredients (1-2\%) ${ }^{[5]}$. Plasma contains blood cells of whole blood, proteins (albumin, globulin and fibrinogen), glucose, clotting factors, electrolytes, hormones and carbon dioxide. The most indispensable cation ions are $\mathrm{Na}^{+}, \mathrm{K}^{+}, \mathrm{Ca}^{2+}, \mathrm{Mg}^{2+}$ and anion ions like $\mathrm{Cl}^{-}, \mathrm{P}^{2+}$, $\mathrm{PO}_{3}-\mathrm{SO}_{4}{ }^{-}, \mathrm{NaH}_{2} \mathrm{PO}_{4}, \mathrm{Na}_{2} \mathrm{HPO}_{4}$ and microelements like $\mathrm{Fe}^{2+}, \mathrm{Cu}^{2+}, \mathrm{Zn}^{2+}, \mathrm{Co}^{2+}, \mathrm{J}^{-[6,17}$. The most common blood salts, $\mathrm{NaCl}$ and $\mathrm{NaCO}_{3}$, regulates osmotic pressure and chemical reactions. ${ }^{[7]}$.

Urine is a renal product of organic and inorganic material, a bright liquid with a light yellow colour, specific smell and salt-bitter taste ${ }^{[8]}$. The founded state of metabolism and nutrition causes changes in Urine constituent in the physiological and non-physiological range. The colour of Urine depends on constituent concentration, pigments and pathological content. Urine contains $95-97 \%$ water and 3-5\% diluted material. Inorganic constituents are $\mathrm{Na}^{+}, \mathrm{K}^{+}, \mathrm{Ca}^{2+}, \mathrm{Mg}^{2+}, \mathrm{NH}_{4}$ and anion $\mathrm{Cl}^{-}, \mathrm{P}^{2+}, \mathrm{HCO}_{3}{ }^{-}, \mathrm{SO}_{4}{ }^{2-[8]}$. Organic components can be nitrogen and non-nitrogen ${ }^{[8]}$. Nitrogen materials are urea, creatinine_Cr, uric acid, amino acid, while non-nitrogen materials belong to phenol, oxalate, glucuronic acid and milky acid ${ }^{[8]}$. A small number of ferments, hormones and vitamins are present ${ }^{[8]}$. Intercellular fluids are relatively constant fluids, while tissue fluid and blood plasma are inconstant to change ${ }^{[1]}$. Maintaining organism homeostasis is significant for permanent composition and volume of body fluid (1). Human organism contains small water supplies. During the day, 1.5-2I of water evaporates through Urine, faeces, lung sweat and skin ${ }^{[20]}$. Knowledge about biological and chemical processes affects establishing reference range, disease diagnosis, prognosis and follow-up.

Sustainable effort must obtain for sensitivity, specificity, robustness and reproducibility of data. Preanalytical factors influence sample quality; reproducibility, stability and false-positive results. ${ }^{[9]}$. Preanalytic variables include 3. categories, physiologic (age, gender, sex, time, season, altitude, menstruation, pregnancy, lifestyle like diet, caffeine, ethanol, smoking), specimens collection (overnight fasting, time of specimen collection, posture during sampling, exercise, water intake, anticoagulants-blood ratio, specimen handling and processing, added additives with anticoagulants), and influence or interference factors (drug metabolites, laboratory tests, collection tube) affecting variable range ${ }^{[9]}$. Information about water intake and sampling enable appropriate diagnostic and therapeutic strategy for human disease monitoring and treatment. Water intake, a pre-analytical variable, contributes to biochemical processes and affects establishing reference range, disease diagnosis, prognosis and follow-up ${ }^{[10]}$. Studies analyzed conditions like storage time, temperature, freezing-thawing cycle on biomarker range and reproducibility ${ }^{[9]}$. Despite increasing sensitivity of methodology for determining biomarker range, discrepancies among variables exist in the literature due to sampling frequency, sample and pre- 
analytical factor interaction complexity ${ }^{[9]}$. Critical aspects of biomarker results, stability during clinical planning, sample collection, training, selection of sample preservation, buffers, shipping, logistics and method analysis is known for the most utilized bio-specimens ${ }^{[9]}$. Urine and Blood samples are the most commonly used in clinical practice reflecting state of metabolome and metabolic end product ${ }^{[10]}$. Few researchers correlated Urine and Blood parameters with water intake in healthy participants. The relationship between hydration, Urine/Blood biomarker and total fluid intake in pregnant and lactating women during 3 semesters is estimated ${ }^{[11]}$. Observational studies recorded and assessed the amount of firm food/ beverage and Urine parameters (osmolarity, volume, gravity and colour) in healthy children and elderly individuals for 24h [12, 13]. A cross-sectional study on healthy Male college students in China assed hydration status, fluid intake and Urine biomarker (osmolarity, specific gravity, $\mathrm{pH}$, the concentration of $\mathrm{K}^{+}$, $\mathrm{Na}^{+}$and $\left.\mathrm{Cl}^{2-}\right)$ for 24 hours ${ }^{[14]}$. Moreover, Urine hydration biomarker $\left(\mathrm{PO}_{4}^{-}\right.$, Uric acid, Urea, $\mathrm{Cr} \mathrm{K}^{+}, \mathrm{Na}^{+}, \mathrm{Mg}^{2+}$, $\mathrm{Ca}^{2+}$ ) for 24 hours is analyzed ${ }^{[15]}$. Change in Blood biomarkers (Whole Blood cells, Erythrocyte_ER, Haemoglobin_Hg, Hematocrite_Ht, Mean Corpuscular Volume_MCV, Mean Corpuscular Hemoglobin_MCH, Mean Corpuscular Hemoglobin Concentration_MCHC, Mean Platelet Volume_MPV, Trombocytes_TR) in the control_C and test_T group on $1^{\text {st }}$ day and two weeks later is determine ${ }^{[16]}$. Urea concentrations in Blood samples after freezing at -80 degrease is analyzed ${ }^{[17]}$. Fluid intake habits and sample sampling effect on Urine and Blood biomarkers of healthy participants lack in literature. Sample sampling can lead to results bias. Protocol for sample collection frequency, handling, and storage ensure reliable analysis of disease in routine practice and clinical trials ${ }^{[18]}$. Daily circadian rhythm influence physiological processes and diurnal dynamic ${ }^{[19]}$. Time-of-day-dependent oscillations in Blood level molecules could be a potential cause of variability in laboratory results, making sampling time an important consideration ${ }^{[19]}$.

Blood and Urine biomarker change during the regime of 9 consecutive days of water intake in healthy participant lack. There is a lack of literature about the effect of water intake regime and sample sampling as a pre-analytical factor influencing Blood and Urine biomarker range in healthy subjects. A current study was done as a part of the $\mathrm{PhD}$ thesis aim to examine the effect of 7 and 9-day regime water intake in Test (T) and Control (C) group on 7-Blood (Freezing point depression_FPD, Potassium_K $\mathrm{K}^{+}$, Sodium_Na ${ }^{+}$, Chloride_Cl', Urea, Creatinine_Cr, Urate) and 17-Urine (Urea, Cr, Urat, Glucose_Glu, C reactive protein_CRP, Leucocyte_LE, Erythrocyte_ER, Hemoglobine_Hg, Hematocrit_Ht, Mean Corpuscular Volume_MCV, Mean Corpuscular Hemoglobin_MCH, Mean Corpuscular Hemoglobin Concentration_MCHC, MPV_Mean Platelet Volume, Trombocyte_TR, $\mathrm{K}^{+}, \mathrm{Na}^{+}, \mathrm{Cl}^{-}$) parameters in healthy subjects, during 2 sample collection, depending on gender and water intake level. Hypothesis postulate that water intake affects the reference range of Urine and Blood biomarkers.

\section{Material And Methods}

\section{Study group and Human biological material dataset}

Experiments were performed according to ethical standards and with the written consent of the Blood donors. Permission from the National Medical Ethics Committee, number 82/07/14, is given. The human 
Blood and Urine information dataset obtain from the collaborative institution.

Participants differ by Gender (Male_M; Female_F), the amount of drinking water, Blood and Urine parameter values. The total number of participants consists of 23 healthy participants $(F=9, M=14)$. $M$ $(60.9 \%)$ were numerous in comparing to $F(39.1 \%)$ participants. Mean water intake for 5 days, is recorded. An upward trend in the $T$ group and downward in the $\mathrm{C}$ group exists. The $\mathrm{T}$ group drank more than 1800 $\mathrm{ml}$ with a mean water intake value of $2055 \mathrm{ml}$. The $\mathrm{C}$ group consumed less than $2000 \mathrm{ml}$, with a mean water intake value of $1846 \mathrm{ml}$. The number of M/F participants in the T/C group varies. The 14 subjects in the T group [M:(9/23); F:(5/23)] represent $39.12 \% \mathrm{M}$ and $21.74 \% \mathrm{~F}$ of the total participant. Meanwhile, 9 subjects in the $\mathrm{C}$ group [M:(5/23); F:(4/23)] represent $21.74 \% \mathrm{M}$ and $17.4 \% \mathrm{~F}$-number of the total participant.

The regime of water intake for 23 healthy subjects included 5-days of controlled water consumption, 2days of arbitrary higher water intake in the $T$ group before $1^{\text {st }}$ sampling $\left(7^{\text {th }}\right.$-day of water intake), 2-days of desired lover water intake in the $T$ group before $2^{\text {nd }}$ sampling ( $9^{\text {th }}$-day of water intake), while $C$ group drank the same level of water during $1^{\text {st }}$ and $2^{\text {nd }}$ sampling. Of the total M/F participants, 7-Urine and 14 Blood (Urea, Creatinine, Urate, Glucose, CRP, LE, ER, Hg, Ht, MCV, MCH, MCHC, MPV, TR) variables tested for a change. On 11 male participants, 3 additional electrolytes $\left(\mathrm{Na}^{+}, \mathrm{K}^{+}, \mathrm{CL}^{-}\right)$test for a change.

\section{Statistical analysis}

IBM-SPSS software v23.0 applies for statistical data analysis. Descriptive statistics, Shapiro-Wilk normality test, parametric and non-parametric statistical tests such as Paired and Independent T-test, Wilcoxon and Mann-Whitney/Kruskal-Wallis test is employed. Results display mean (SD) and p-value. A statistically significant correlation was assumed when $\mathbf{P}<0.05$.

\section{Results}

\section{Participant information}

Urine and Blood characteristics are present in Table 1 and Table 2. Proposed values of 7 Urine (FPD, $\mathbf{K}$, $\mathrm{Na}, \mathrm{Cl}$, Urea) and 17 Blood (Urea, Cr, Urat, Glu, CRP, Le, ER, Hg, Ht, MCV, MCH, MCHC, MPV, TR, Na, K, Cl) biomarker are subject to change during 1 st and 2nd sampling. Shapiro-Wilk test indicated the presence of normality $(\mathrm{P}>0.05)$ for $\mathrm{FPD}, \mathrm{K}^{+}, \mathrm{Na}^{+}, \mathrm{Cl}, \mathrm{Cr}$ and Urate during $2^{\text {nd }}$ sampling and Urea during $1^{\text {st }}$ sampling in Urine samples and for Glucose, MPV during $2^{\text {nd }}$ sampling, Urea, Urate, Ht, MPV during $1^{\text {st }}$ sampling and $\mathrm{K}^{+}$during $1^{\text {st }}$ and $2^{\text {nd }}$ sampling in Blood samples. All other variables showed an absence of normality $(P<0.05)$. All non-parametric data transform to normality using log transformation, except for CRP and additional electrolytes in the Blood. Based on this notion, the parametric and non-parametric test is employed. 
Paired T-test revealed a statistically significant difference $(P<0.01,95 \% \mathrm{Cl})$ between the $1^{\text {st }}$ and $2^{\text {nd }}$ sampling for FPD, $\mathrm{Na}^{+}, \mathrm{K}^{+}, \mathrm{Cr}$, Urea, Urate in Urine and Urea, Urate, $\mathrm{Glu}, \mathrm{Ht}$, TR in Blood. Wilcoxon T-test shows the absence of a statistically significant difference $(P>0.05, a=0.05,95 \% \mathrm{Cl})$ for CRP in Blood. Results match with Mann-Whitney and Kruskal-Wallis test. The difference between the T/C group confirms independent T-test for FPD ( $P<0.01), \mathrm{K}^{+}(P<0.05), \mathrm{Na}^{+}(P<0.01), \mathrm{Cl}^{-}(P<0.05), \mathrm{Cr}(\mathrm{P}<0.05)$, Urate $(P<0.01)$ and Urea $(P<0.05)$ in Urine after $1^{\text {st }}$ sampling and $\mathrm{K}^{+}(P<0.01)$ and $\mathrm{Cl}^{-}(P<0.01)$ after $1^{\text {st }}$ sampling in Blood. Figure 1. shows the difference between test and control group for $1^{\text {st }}$ and $2^{\text {nd }}$ sampling in Blood and Urine. Gender difference confirmed for Urea $(P<0.05)$ variable after $2^{\text {nd }}$ sampling in Urine and for Urate $(P<0.01 / 0.05)$, Glu $(P<0.01 / 0.05)$ and $\mathrm{Ht}(P<0.01 / 0.05)$ after $1^{\text {st }}$ and $2^{\text {nd }}$ sampling and $\mathrm{MCHC}$ $(P<0.05)$ during $2^{\text {nd }}$ sampling in Blood.

\section{Discussion}

Understanding physiological changes enhance the quality interpretation of subject information. Investigating water intake regimes and days of sampling contribute to understanding the physiological response. Proper hydration can have a beneficial effect on human health ${ }^{[2,3]}$. The literature contains insufficient information regarding the optimal amount of water intake for disease prevention, linkage of water amount and health outcome. Epidemiological data failed to provide appropriate health evaluation. The effects of water consumption on Blood and Urine samples are analyzed. Usually, studies examined the influence of 1.3-4l/per day water intake for 1 and 3 days, 1 st and 3 rd gestation week in healthy female/male participants, aged 18-83 years. The analysis contains a generation gap between 40-60 years of age.

Parameter changes of $\mathrm{pH}$, colour, volume, osmolarity, specific gravity, phosphate, uric acid, $\mathrm{Urea}, \mathrm{Cr}, \mathrm{K}^{+}$, $\mathrm{Na}^{+}, \mathrm{Cl}^{2-}, \mathrm{Mg}^{2+}$ and citrate in Urine samples were assessed $[11,12,14,15]$. Literature results from $24 \mathrm{~h}$ Urine sample analysis indicated the presence of discrepancy in correlated data and that different average water intake amount and proposed methodology affect parameter relation. The study reveals the association of total fluid intake with Urine colour, osmolarity, specific gravity and solute concentration ${ }^{[13]}$. The crosssectional analysis showed the association of Urine volume with osmolarity, gravity and osmolarity, osmolarity and colour, colour and gravity ${ }^{[12,14]}$. There are no publications regarding the influence of 5 days water intake combined with 2 days of arbitrary consumption of large water amount till $1^{\text {st }}$ sampling and lower water amount till $2^{\text {nd }}$ sampling in T group and continuous water intake in $\mathrm{C}$ group during $1^{\text {st }}$ and $2^{\text {nd }}$ sampling on Blood and Urine parameters in healthy individuals, as this is the case with this study.

Descriptive statistic details regarding subjects contribute to characteristics of Blood and Urine parameter change and correctness of the report by data collection and analysis. A subject profile, who took part in the survey, was developed. Age and Gender variables are present. Duration of water intake, sample sampling and influence is assessed. Quality control implements for data selection, analysis and interpretation. Reliability and validity are high, confirmed by the accuracy of measurements and 
correlation value. This study has high standardization of the pre-analytical factors. Describes, justifies and discuss the research topic. Normally distributed data as a structural model of the Shapiro Wilk test is utilized in the analysis. Non-normal data converts to normal. Results are quantified. Preliminary results established research validity with statistical significance $(P<0.01,0.05)$. Basic statistical methodology compares the test and control group of participant data. Results identified the correlation between multiple covariates in healthy participants indicating the importance of knowledge of appropriate statistics. The study has a short term follow up, 7 and 9 days considered in the analysis.

The amount of water intake, diseases, usage of drugs and profession type can lead to electrolyte misbalance resulting in quality and interpretation, further prognosis, diagnosis and patient follow-up [20, 21]. In this study for 5 days, F drank a higher water amount comparing to $M$. In this study, the percentage difference between genders exists for Urea (52.22\%) after $2^{\text {nd }}$ sampling in Urine. In Blood for Urate (1st:15.16\%; 2nd:14.5\%), Glu (1st:13.63\%; 2nd:8.7\%), Ht (1st and 2nd:7.23\%) during $1^{\text {st }}$ and $2^{\text {nd }}$ sampling and $\mathrm{MCHC}(2.1 \%)$ during $2^{\text {nd }}$ sampling. Males have higher values in comparing to females. Sex hormones affect gender differences ${ }^{[22-25]}$. Female sex hormones (Estrogen) regulate the activity of glucose and urate transporters (ABCG2 and SLC2A9), having different transporter expression (transcription, post-translational modification), localization and activity ${ }^{[22,23]}$. Male sex hormones (Testosterone) affect $\mathrm{MCHC}$ and $\mathrm{Ht}$ level through the increase of erythropoietin, reduction of ferritin and hepcidin ${ }^{[24]}$. Testosterone influence protein metabolism and the Urea cycle ${ }^{[25]}$.

Drinking more water improves kidney function and clearance of toxins by glomerular filtration, tubular secretion, and activation of various degradative metabolic pathways ${ }^{[26]}$. Results indicate that water intake influence Urine [FPD (86.5\%), K+ (81.7\%), Na+ (104.1\%), Cl- (97.37\%), Urea (75.34\%), Cr (116.45\%), Urat (89.65\%)] and Blood [K+ (9.5\%), $\mathrm{Cl}-(3.92 \%)]$ during $1^{\text {st }}$ sampling. There is a link between water intake and homeostatic mechanisms to maintain water balance and health outcomes. Urine osmolarity depends on cations, $\mathrm{Na}+\mathrm{K}+, \mathrm{NH} 4+$, anions and Urea, whereas FPD enables estimation of Urine osmolality [27, 28]. Freezing point depression as a colligative property depends on the molality of the solute ${ }^{[29]}$. Renal $\mathrm{Cr}$ excretion level depends on the glomerular filtration rate, proximal tubular secretion and OCT-2 transporter $[30,31]$. Higher water intake after 3 . days causes a decrease of uric acid, up-regulation of GLUT9 and URAT1 and down-regulation of ABCG2 and OAT1, while after 7. days affect NPT1 down-regulation in hyperuricemia mice ${ }^{[32]}$. Urate level depends on transport proteins (URAT1 and GLUT9), uricase inactivation and possible change of the intestinal microbiota ${ }^{[32]}$. Production of concentrated Urine

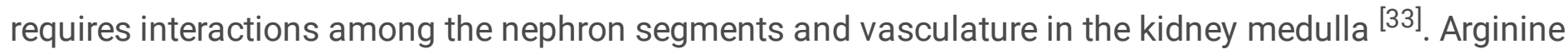
vasopressin (AVP) is a crucial molecule in water homeostasis. Increase water intake, decrease AVP, reduce risk of renal and metabolic diseases and improve health outcome ${ }^{[33]}$. Vasopressin regulates Urea transport acutely by increasing UT-A1 phosphorylation and the apical plasma-membrane accumulation of UT-A1 through two cAMP-dependent pathways ${ }^{[34]}$. Glut9 plays a role in urate homeostasis by its dual role in urate handling in the kidney and uptake in the liver ${ }^{[35]}$. Small water intake can lead to dehydration, activation of the renin-angiotensin system (RAS) through angiotensin receptors and subsequent 
activation of signalling molecules, protein kinase $\mathrm{C}$, reactive oxygen species, MAP kinase pathway mediated with angiotensin ${ }^{[36]}$. Prolactin, aldosterone and antidiuretic hormone influences water metabolism and electrolyte balance ${ }^{[37-46]}$.

Results show higher concentration percentage increase in variables from Urine [FDP (68\%), Na+ (62.96\%), $\mathrm{K}+(21.88 \%), \operatorname{Cr}(65.2 \%)$, Urat (69.2\%), Urea (96.27\%)] in comparing to Blood [Urea (10.5\%), Urate (7.1\%), Glu (2.2\%), Ht (2.43\%), TR (3.9\%)] between 1st and 2nd sampling of 7th and 9th day of water intake. Studies indicate that daily water intake in healthy Japanese adults' decrease blood pressure, $\mathrm{Ht}$, Urine gravity and a rise in body temperature ${ }^{[39]}$. Lower and steady daily water intake increase $\mathrm{Cr}$, Cortisol, Urea, Uric acid, $\mathrm{Na}+, \mathrm{Hg}$; decrease CRP, and have no change in $\mathrm{Ht}$, active rennin, aldosterone and plasma osmolality $[16,47,48]$.

Ex vivo cellular injury, disintegration, cellular granule release and protease activation causes alterations of cell release in vitro after sampling ${ }^{[49]}$. Hydration biomarkers in $24 \mathrm{~h}$ Urine correlate with daily total fluid intake volume in sedentary adults in free-living conditions ${ }^{[15]}$. Literature findings follow the results of the study. Explain differences in concentration changes of healthy participants due to water intake and sample sampling.

\section{Conclusions}

Information about the water regime during 7-9 days and gender in healthy participants positively impact further clinical studies on disease patients. Water intake and sample sampling change Blood and Urine biomarker concentration. Future work should emphasize disadvantages by comparing health/disease states to draw clinically applicable conclusions. Advantage of the study is clinical reproducibility, applicability, fast and precise insight into physiological changes. Descriptive and preliminary results can be a reference point for protocol standardization and quality control check. Lead the improvement of healthcare service. The study disadvantage is the number of participants and the absence of additional information (habits, demography and genetic analysis). Change of Blood and Urine parameters represents the clinical outcome. Demographic characteristics are not analyzed. The comparison between the water intake group, sample sampling and gender are analyzed. Methodology for determining the range of Blood and Urine parameter is missing. Subjects who are missing data regarding water intake do not participate in the study. The hypothesis justifies concepts from the previous studies.

\section{Abbreviations}

Arginine vasopressin (AVP), Chloride_Cl', Control_C, Creatinine_Cr, C reactive protein_CRP, Erythrocyte_ER, Female_F, Freezing point depression_FPD, Glucose_Glu, Hematocrit_Ht, Hemoglobine_Hg, Leucocyte_LE, Male_M, Mean Corpuscular Volume_MCV, Mean Corpuscular Hemoglobin_MCH, Mean Corpuscular Hemoglobin Concentration_MCHC, MPV_Mean Platelet Volume, Potassium_K' $\mathrm{K}^{+}$Sodium_Na ${ }^{+}$, Test_T, Trombocyte_TR, 


\section{Declarations}

\section{Acknowledgement}

I want to acknowledge the kind support of my CEEPUS-freemover mobility mentor from Slovenia, prof. Dr Damjana Drobne. Prof. Dr Damjana gave me the opportunity to work on this subject by ensuring me samples and place between the research rooftop. She was kind to accept me to work with her on a project, to finalize my PhD thesis through CEEPUS freemover mobility network, and establish close collaboration between Universities. She introduced me closer to academia and scientific research. I also want to acknowledge my dear colleges from the Biotechnical faculty, M.Sc Alenka Malovrh, PhD student Neža Repar, and other team members of Bionanoteam who introduced me to practical scientific work in the laboratory and student mentoring. Prof. Dr Veronika Kralj Iglic, Pl, gave me information about the project J5-7098, on which I worked through CEEPUS freemover mobility.

I want to thank all the people who contributed to my education and my parents for the continuously given love and support. Thank you all for being a part of this lovely Snežana (Snow White) story, my life story. Life writes novels.

\section{Funding}

This research did not receive any specific grant from funding agencies in the public, commercial, or notfor-profit sectors. CEEPUS freemover PhD student program mobility and project J5-7098, "Assessment of Blood parameters and extracellular vesicles for optimization of sport results" (PI Veronika Kralj-lglic), enabled collaboration between the Biotechnical Faculty, University of Ljubljana, Slovenia and the University of Belgrade, Serbia with prof. Dr Damjana Drobne mentoring and accomplishment of the experimental part of the $\mathrm{PhD}$ thesis.

\section{Availability of data materials}

Data are available in Table 1 and 2.

\section{Ethical approval and consent to participate}

Experiments were performed according to ethical standards and with the written consent of the sample donors. Permission from the National Medical Ethics Committee, number 82/07/14, is given.

\section{Consent for publication}

"Not applicable"

\section{Competing interest}

The author, a PhD student, Snežana Jovičić, declare no competing interest.

\section{Author's contribution}


Author (Snežana Jovičić, PhD student at the Faculty of Biology, University of Belgrade, Serbia), originated data collection, analysis, interpretation and writing. The author made all the effort, accuracy, integrity and quality. The author approves the final version of the presented manuscript for submission. The author confirms that this work is original and has not been published elsewhere, nor is it currently under consideration for publication elsewhere.

\section{Author's information}

Snežana Jovičić, a PhD student, is born on 17.10.1990 in Belgrade, Serbia. Academic qualifications: enrolment of PhD studies, Genetics (2014). Snežana Jovičić finished M.Sc. Human Molecular biology, (2014) and B.Sc. Molecular Biology and Physiology (2013).

\section{Author Details}

${ }^{1}$ Department of Genetics, Faculty of Biology, University of Belgrade, Belgrade, Serbia

\section{References}

1. Ramachandran VS. .Encyclopedia of Human Behaviour ( $2^{\text {nd }}$ edition). In: Asarian L, Gloy V, Geary N., editors. Homeostasis. Reference module in Neuroscience and Behavioural psychology. London; Burlington, MA: Elsevier/Academic Press, 2012. 324-33.

2. Levy Y, Onuchic JN. Water mediation in protein folding and molecular recognition. Annu Rev Biophys Biomol Struct. 2006;35:389-415.

3. Popkin BM, D'Anci KE, Rosenberg IH. Water, hydration, and health. Nutr Rev. 2010;68(8):439-58.

4. Jacob M, Chappell D, Becker BF. Regulation of blood flow and volume exchange across the microcirculation. Crit Care. 201621;20(1):319.

5. Mathew J, Sankar P, Varacallo M. Physiology, Blood Plasma. StatPearls; 2020. https://www.ncbi.nlm.nih.gov/books/NBK531504/. Accessed 17 Nov 2020.

6. Wilkerson JE, Horvath SM, Gutin B, Molnar S, Diaz FJ. Plasma electrolyte content and concentration during treadmill exercise in humans. Journal of Applied Physiology 1982; 53(6):1529-39.

7. Ashton N. Physiology of red and white blood cells. Anaesthesia \& Intensive Care Medicine 2013;14(6):261-6.

8. Putnam DF. Composition and concentrative properties of human urine.:https://ntrs.nasa.gov/api/citations/19710023044/downloads/19710023044.pdf Accessed: 23 Feb 2021

9. Narayanan S: The preanalytic phase. An important component of laboratory medicine. Am J Clin Pathol. 2000;113(3):429-52.

10. Yin P, Lehmann R, Xu G: Effects of pre-analytical processes on blood samples used in metabolomics studies. Anal Bioanal Chem. 2015;407(17):4879-92. 
11. McKenzie AL, Perrier ET, Guelinckx I, Kavouras SA, Aerni G, Lee EC, et al. Relationships between hydration biomarkers and total fluid intake in pregnant and lactating women. Eur J Nutr 2017;56(6):2161-70.

12. Athanasatou A, Kandyliari A, Malisova O, Kapsokefalou M. Fluctuation of Water Intake and of Hydration Indices during the Day in a Sample of Healthy Greek Adults. Nutrients 2019;11(4):793.

13. Kavouras SA, Bougatsas D, Johnson EC, Arnaoutis G, Tsipouridi S, Panagiotakos DB. Water intake and urinary hydration biomarkers in children. Eur J Clin Nutr 2017;71(4): 530-5.

14. Zhang N, Du S, Tang Z, Zheng M, Yan R, Zhu Y, et al. Hydration, Fluid Intake, and Related Urine Biomarkers among Male College Students in Cangzhou, China: A Cross-Sectional Study-Applications for Assessing Fluid Intake and Adequate Water Intake. Int J Environ Res Public Health 2017; 14(5):513.

15. Perrier E, Rondeau P, Poupin M, Le Bellego L, Armstrong LE, Lang F, et al. Relation between urinary hydration biomarkers and total fluid intake in healthy adults. Eur J Clin Nutr 2013;67(9):939-43.

16. Hyun-Kyung K, Kim SH, Ryu JK. Changes in the Blood components caused by water intake. Korean J of Clinical and Laboratory Science 2017;49(3): 227-32.

17. Armstrong LE, Johnson EC, McKenzie AL, Munoz CX. Interpreting common hydration biomarkers on the basis of solute and water excretion. Eur J Clin Nutr 2013;67(3): 249-53.

18. Hansson O., Mikulskis A., Fagan A.M., Teunissen C., Zetterberg H., Vanderstichele H. The impact of preanalytical variables on measuring cerebrospinal fluid biomarkers for Alzheimer's disease diagnosis: A review. Alzheimers Dement. 2018;14:1313-33.

19. Ournier S., Iten L., Marques-Vidal P., Boulat O., Bardy D., Beggah A. Circadian rhythm of blood cardiac troponin T concentration. Clin Res Cardiol. 2017;106:1026-32.

20. Puga AM, Lopez-Oliva S, Trives C, Partearroyo T, Varela-Moreiras G: Effects of Drugs and Excipients on Hydration Status. Nutrients, 2019,11(3):669.

21. Liska D, Mah E, Brisbois T, Barrios PL, Baker LB, Spriet LL: Narrative Review of Hydration and Selected Health Outcomes in the General Population. Nutrients, 2019,11(1):70.

22. Zhang Y, Howard BV, Cowan LD, Yeh J, Schaefer CF, Wild RA, Wang W, Lee ET: The effect of estrogen use on levels of glucose and insulin and the risk of type 2 diabetes in american Indian postmenopausal women: the strong heart study. Diabetes Care. 2002, 25(3):500-4.

23. Halperin Kuhns VL, Woodward OM: Sex Differences in Urate Handling. Int J Mol Sci. 2020, 21(12):4269.

24. Paller CJ, Shiels MS, Rohrmann S, Menke A, Rifai N, Nelson WG, Platz EA, Dobs AS: Association between sex steroid hormones and hematocrit in a nationally representative sample of men. J Androl. 2012, 33(6):1332-41.

25. Lam T, Poljak A, McLean M, Bahl N, Ho KKY, Birzniece V: Testosterone prevents protein loss via the hepatic urea cycle in human. Eur J Endocrinol. 2017, 176(4):489-96.

26. Negoianu D, Goldfarb S. Just add water. J Am Soc Nephrol. 2008, 19(6):1041-3. 
27. Youhanna S, Bankir L, Jungers P, Porteous D, Polasek O, Bochud M, Hayward C, Devuyst O: Validation of Surrogates of Urine Osmolality in Population Studies. Am J Nephrol, 2017, 46(1):26-36.

28. Perrier ET, Buendia-Jimenez I, Vecchio M, Armstrong LE, Tack I, Klein A: Twenty-four-hour urine osmolality as a physiological index of adequate water intake. Dis Markers, 2015, 2015:231063.

29. Feher J. Quantitative Human Physiology. An introduction. In. Osmosis and Osmotic pressure. $2^{\text {nd }}$ Elsevier. USA: 2017:182-98.

30. Musso CG, Oreopoulos DG: Aging and Physiological Changes of the Kidneys Including Changes in Glomerular Filtration Rate. Nephron Physiol, 2011, 119(1):1-5.

31. Ciarimboli G, Lancaster CS, Schlatter E, Franke RM, Sprowl JA, Pavenstädt H, Massmann V, Guckel D, Mathijssen RH, Yang W, Pui CH, Relling MV, Herrmann E, Sparreboom A: Proximal tubular secretion of creatinine by organic cation transporter OCT2 in cancer patients. Clin Cancer Res, 2012, 18(4):11018.

32. Wen S, Wang D, Yu H, Liu M, Chen Q, Bao R, Liu L, Zhang Y, Wang T: The Time-Feature of Uric Acid Excretion in Hyperuricemia Mice Induced by Potassium Oxonate and Adenine. Int J Mol Sci, 2020, 21(15):5178.

33. Guelinckx I, Vecchio M, Perrier ET, Lemetais G: Fluid Intake and Vasopressin: Connecting the Dots. Ann Nutr Metab. 2016;68(Suppl 2):6-11.

34. Sands JM, Blount MA, Klein JD: Regulation of renal urea transport by vasopressin. Trans Am Clin Climatol Assoc. 2011;122:82-92.

35. Preitner F, Bonny O, Laverrière A, Rotman S, Firsov D, Da Costa A, Metref S, Thorens B:. Glut9 is a major regulator of urate homeostasis and its genetic inactivation induces hyperuricosuria and urate nephropathy. Proc Natl Acad Sci U S A. 2009;106(36):15501-6.

36. Coble JP, Grobe JL, Johnson AK, Sigmund CD: Mechanisms of brain renin angiotensin systeminduced drinking and blood pressure: importance of the subfornical organ. Am J Physiol Regul Integr Comp Physiol. 2015;308(4):R238-R249.

37. Alamer M: The Role of Prolactin in Thermoregulation and Water Balance During Heat Stress in Domestic Ruminants. Asian Journal of Animal and Veterinary Advances. 2011;6(12):1153-69.

38. Kenyon CJ, Saccoccio NA, Morris DJ: Aldosterone effects on water and electrolyte metabolism. J Endocrinol. 1984;100(1):93-100.

39. Andersson B, Leksell LG, Rundgren M: Regulation of water intake. Annu Rev Nutr. 1982;2:73-89.

40. Burstyn PG: Sodium and water metabolism under the influence of prolactin, aldosterone, and antidiuretic hormone. J Physiol. 1978;275:39-50.

41. Falconer IR, Rowe JM: Effect of prolactin on sodium and potassium concentrations in mammary alveolar tissue. Endocrinology. 1977;101(1):181-6.

42. Kulczycki LL, Robertson MT: The sweat chloride concentration and prolactin activity in cystic fibrosis. Scand J Gastroenterol Suppl. 1988;143:28-30. 
43. Scott JH, Menouar MA, Dunn RJ: Physiology, Aldosterone. [Updated 2020 Jul 26]. In: StatPearls [Internet]. Treasure Island (FL): StatPearls Publishing; 2020 Jan-. Available from:https://www.ncbi.nlm.nih.gov/books/NBK470339/.

44. Work J, Galla JH, Booker BB, Schafer JA, Luke RG: Effect of ADH on chloride reabsorption in the loop of Henle of the Brattleboro rat. Am J Physiol. 1985;249(5 Pt 2):F698-703.

45. Lorenz JM. Chapter 3 - Potassium Metabolism. In: William Oh, Jean-Pierre Guignard, Stephen Baumgart, Richard A (editors). Polin,Nephrology and Fluid/Electrolyte Physiology: Neonatology Questions and Controversies,W.B. Saunders; 2008;54-65.

46. Young DB, Pan YJ, Guyton AC: Control of extracellular sodium concentration by antidiuretic hormonethirst feedback mechanism. Am J Physiol, 1977;232(5): R145-9.

47. Unal K: The effect of daily water intake on blood biochemical markers in healthy individuals. Turkish journal of Occupational/Environmental medicine and safety, 2017;2:1(3):230-7.

48. Benozzi SF, Unger G, Campion A, Pennacchiotti GL: Fasting conditions: Influence of water intake on clinical chemistry analytes. Biochem Med (Zagreb), 2018;28(1): 010702.

49. Kang HJ, Jeon SY, Park JS, Yun JY, Kil HN, Hong WK, Lee MH, Kim JW, Jeon JP, Han BG: Identification of clinical biomarkers for pre-analytical quality control of blood samples. Biopreserv Biobank. 2013;11(2):94-100.

\section{Tables}

Table 1. Urine parameter value during $1^{\text {st }}$ and $2^{\text {nd }}$ sampling 


\begin{tabular}{|c|c|c|c|c|c|}
\hline \multirow[t]{3}{*}{ Table 1. Participant Urine parameter } & & \multicolumn{4}{|c|}{ Participants group } \\
\hline & & \multicolumn{2}{|l|}{ Control } & \multicolumn{2}{|l|}{ Test } \\
\hline & & Mean & $\begin{array}{l}\text { Standard } \\
\text { Deviation }\end{array}$ & Mean & $\begin{array}{l}\text { Standard } \\
\text { Deviation }\end{array}$ \\
\hline \multirow{2}{*}{$\begin{array}{l}\text { Freezing point depression }(\mathrm{mK}){ }_{-} 1^{\text {st }} \\
\text { sampling }\end{array}$} & Female & 852.75 & 591.82 & 479.40 & 240.33 \\
\hline & Male & 1072.00 & 455.10 & 334.44 & 103.97 \\
\hline \multirow{2}{*}{$\begin{array}{l}\text { Freezing point depression ( }(\mathrm{mK}) 2^{\text {nd }} \\
\text { sampling }\end{array}$} & Female & 752.50 & 287.25 & 858.40 & 380.45 \\
\hline & Male & 1000.20 & 362.34 & 1283.44 & 579.44 \\
\hline \multirow[t]{2}{*}{$\mathrm{K}$ (mmol/L)_ $1^{\text {st }}$ sampling } & Female & 37.50 & 19.23 & 27.40 & 13.72 \\
\hline & Male & 59.20 & 28.58 & 17.56 & 9.61 \\
\hline \multirow[t]{2}{*}{$\mathrm{K}$ (mmol/L)_2 ${ }^{\text {nd }}$ sampling } & Female & 23.75 & 8.46 & 38.20 & 18.09 \\
\hline & Male & 51.40 & 19.45 & 39.00 & 17.20 \\
\hline \multirow[t]{2}{*}{$\mathrm{Na}$ (mmol/L)_1 ${ }^{\text {st }}$ sampling } & Female & 82.25 & 65.51 & 38.40 & 15.42 \\
\hline & Male & 99.80 & 48.02 & 23.89 & 8.67 \\
\hline \multirow[t]{2}{*}{$\mathrm{Na}$ (mmol/L)_2 $2^{\text {nd }}$ sampling } & Female & 103.50 & 57.74 & 68.00 & 25.09 \\
\hline & Male & 101.00 & 61.56 & 84.56 & 47.67 \\
\hline \multirow[t]{2}{*}{$\mathrm{Cl}$ (mmol/L)_ $1^{\text {st }}$ sampling } & Female & 77.50 & 64.92 & 49.40 & 18.69 \\
\hline & Male & 140.80 & 73.65 & 33.56 & 13.00 \\
\hline \multirow[t]{2}{*}{$\mathrm{Cl}$ (mmol/L)_2 ${ }^{\text {nd }}$ sampling } & Female & 82.25 & 50.41 & 52.20 & 19.92 \\
\hline & Male & 115.60 & 77.35 & 78.89 & 61.76 \\
\hline \multirow[t]{2}{*}{ Urea (mmol/L)_ $1^{\text {st }}$ sampling } & Female & 188.50 & 145.42 & 111.40 & 70.96 \\
\hline & Male & 210.80 & 85.51 & 80.11 & 44.90 \\
\hline \multirow[t]{2}{*}{ Urea (mmol/L)_2 $2^{\text {nd }}$ sampling } & Female & 144.50 & 58.03 & 216.00 & 126.16 \\
\hline & Male & 212.00 & 70.25 & 370.22 & 188.24 \\
\hline \multirow[t]{2}{*}{$\mathrm{Cr}$ (mmol/L)_ $1^{\text {st }}$ sampling } & Female & 13.08 & 13.43 & 4.26 & 4.23 \\
\hline & Male & 12.06 & 9.09 & 2.84 & 1.68 \\
\hline \multirow[t]{2}{*}{$\mathrm{Cr}(\mathrm{mmol} / \mathrm{L}) 2^{\text {nd }}$ sampling } & Female & 8.25 & 1.63 & 9.68 & 5.54 \\
\hline & Male & 8.88 & 4.40 & 15.07 & 8.59 \\
\hline \multirow[t]{2}{*}{ Urat (mmol/L)_ $1^{\text {st }}$ sampling } & Female & 2.18 & 1.71 & 0.96 & 0.55 \\
\hline & Male & 2.02 & 0.86 & 0.78 & 0.32 \\
\hline
\end{tabular}




\begin{tabular}{|llllll|}
\hline Urat (mmol/L)_2nd sampling & Female & 1.78 & 0.75 & 1.74 & 0.78 \\
\cline { 2 - 6 } & Male & 1.82 & 0.53 & 2.74 & 1.24 \\
\hline
\end{tabular}

Table 2. Blood parameter value during $1^{\text {st }}$ and $2^{\text {nd }}$ sampling 


\begin{tabular}{|c|c|c|c|c|c|}
\hline \multicolumn{2}{|c|}{ Table 2. Participant blood parameter } & \multicolumn{4}{|c|}{ Participants group } \\
\hline & & \multicolumn{2}{|l|}{ Control } & \multicolumn{2}{|l|}{ Test } \\
\hline & & Mean & $\begin{array}{l}\text { Standard } \\
\text { Deviation }\end{array}$ & Mean & $\begin{array}{l}\text { Standard } \\
\text { Deviation }\end{array}$ \\
\hline \multirow[t]{2}{*}{ Urea (mmolL)_1 $1^{\text {st }}$ sampling } & Female & 3.65 & 1.68 & 3.74 & 0.86 \\
\hline & Male & 4.26 & 1.40 & 3.77 & 1.13 \\
\hline \multirow[t]{2}{*}{ Urea (mmolL)_2 $2^{\text {nd }}$ sampling } & Female & 3.60 & 0.82 & 3.82 & 0.68 \\
\hline & Male & 4.32 & 1.43 & 4.51 & 1.67 \\
\hline \multirow[t]{2}{*}{$\mathrm{Cr}$ ( $\mu \mathrm{molL}){ }^{\text {st }}$ sampling } & Female & 72.25 & 9.54 & 61.80 & 4.60 \\
\hline & Male & 67.00 & 6.08 & 72.44 & 10.50 \\
\hline \multirow[t]{2}{*}{$\mathrm{Cr}(\mu \mathrm{molL}) 2^{\text {nd }}$ sampling } & Female & 71.25 & 7.85 & 63.80 & 4.38 \\
\hline & Male & 64.80 & 5.45 & 74.11 & 10.40 \\
\hline \multirow[t]{2}{*}{ Urat ( $\mu$ molL)_ $1^{\text {st }}$ sampling } & Female & 245.50 & 18.63 & 263.60 & 32.53 \\
\hline & Male & 329.80 & 38.23 & 280.00 & 21.17 \\
\hline \multirow[t]{2}{*}{ Urat ( $\mu$ molL)_2 $2^{\text {nd }}$ sampling } & Female & 259.00 & 14.70 & 287.20 & 20.19 \\
\hline & Male & 332.20 & 58.98 & 310.22 & 42.42 \\
\hline \multirow{2}{*}{$\begin{array}{l}\text { Glucose (mmolL)_1 } \\
\text { sampling }\end{array}$} & Female & 4.05 & 0.26 & 4.20 & 0.16 \\
\hline & Male & 4.84 & 0.79 & 4.62 & 0.48 \\
\hline \multirow{2}{*}{$\begin{array}{l}\text { Glucose (mmolL)_2 } \\
\text { sampling }\end{array}$} & Female & 4.25 & 0.24 & 4.46 & 0.30 \\
\hline & Male & 4.92 & 0.57 & 4.67 & 0.45 \\
\hline \multirow[t]{2}{*}{ CRP (mg/L)_ $1^{\text {st }}$ sampling } & Female & 1.00 & 0.00 & 0.80 & 0.84 \\
\hline & Male & 2.80 & 2.59 & 0.67 & 0.50 \\
\hline \multirow[t]{2}{*}{ CRP (mg/L)_2nd sampling } & Female & 1 & 1 & 1 & 2 \\
\hline & Male & 3 & 3 & 1 & 1 \\
\hline \multirow[t]{2}{*}{ LE (109/L)_1 ${ }^{\text {st }}$ sampling } & Female & 6.45 & 0.62 & 6.00 & 0.97 \\
\hline & Male & 5.86 & 1.71 & 6.86 & 1.70 \\
\hline \multirow[t]{2}{*}{ LE (10 $\left.10^{9} / \mathrm{L}\right) 2^{\text {nd }}$ sampling } & Female & 6.8 & 1.1 & 6.6 & 2.1 \\
\hline & Male & 6.0 & 1.4 & 6.6 & 1.3 \\
\hline
\end{tabular}




\begin{tabular}{|c|c|c|c|c|c|}
\hline \multirow[t]{2}{*}{ ER $\left(10^{9} / L\right){ }^{\text {st }}$ sampling } & Female & 4.48 & 0.36 & 4.64 & 0.18 \\
\hline & Male & 4.90 & 0.32 & 4.80 & 0.34 \\
\hline \multirow[t]{2}{*}{ ER $\left(10^{9} / L\right) \_2^{\text {nd }}$ sampling } & Female & 4.5 & 0.4 & 4.7 & 0.3 \\
\hline & Male & 4.9 & 0.4 & 4.8 & 0.4 \\
\hline \multirow[t]{2}{*}{$\mathrm{Hg}(\mathrm{g} / \mathrm{L}) 1^{\text {st }}$ sampling } & Female & 132.00 & 6.78 & 135.20 & 8.14 \\
\hline & Male & 144.20 & 14.97 & 141.56 & 11.06 \\
\hline \multirow[t]{2}{*}{$\mathrm{Hg}(\mathrm{g} / \mathrm{L}) 2^{\text {nd }}$ sampling } & Female & 130 & 8 & 138 & 9 \\
\hline & Male & 143 & 14 & 139 & 12 \\
\hline \multirow[t]{2}{*}{ Ht_1 ${ }^{\text {st }}$ sampling } & Female & 0.39 & 0.01 & 0.40 & 0.02 \\
\hline & Male & 0.43 & 0.04 & 0.42 & 0.03 \\
\hline \multirow[t]{2}{*}{ Ht_2 ${ }^{\text {nd }}$ sampling } & Female & 0.39 & 0.02 & 0.41 & 0.02 \\
\hline & Male & 0.43 & 0.03 & 0.42 & 0.03 \\
\hline \multirow[t]{2}{*}{ MCV (fl)_1 $1^{\text {st }}$ sampling } & Female & 88.25 & 6.18 & 86.80 & 3.03 \\
\hline & Male & 88.00 & 6.20 & 88.33 & 4.95 \\
\hline \multirow[t]{2}{*}{ MCV (fl) $2^{\text {nd }}$ sampling } & Female & 88 & 5 & 87 & 3 \\
\hline & Male & 89 & 7 & 88 & 5 \\
\hline \multirow[t]{2}{*}{ MCH (pg)_1 ${ }^{\text {st }}$ sampling } & Female & 29.50 & 2.08 & 29.00 & 1.00 \\
\hline & Male & 29.60 & 2.51 & 29.56 & 2.24 \\
\hline \multirow[t]{2}{*}{ MCH (pg)_2 $2^{\text {nd }}$ sampling } & Female & 30 & 2 & 30 & 1 \\
\hline & Male & 29 & 2 & 29 & 2 \\
\hline \multirow[t]{2}{*}{ MCHC (g/L)_1 ${ }^{\text {st }}$ sampling } & Female & 335.00 & 8.21 & 337.20 & 6.02 \\
\hline & Male & 334.40 & 5.90 & 334.11 & 8.10 \\
\hline \multirow[t]{2}{*}{ MCHC (g/L)_2 $2^{\text {nd }}$ sampling } & Female & 333 & 9 & 341 & 5 \\
\hline & Male & 328 & 8 & 331 & 10 \\
\hline \multirow[t]{2}{*}{ MPV (fl)_ $1^{\text {st }}$ sampling } & Female & 8.75 & .50 & 8.40 & 0.89 \\
\hline & Male & 9.00 & 1.22 & 7.78 & 0.97 \\
\hline \multirow[t]{2}{*}{ MPV (fl)_2 $2^{\text {nd }}$ sampling } & Female & 9 & 1 & 8 & 1 \\
\hline & Male & 9 & 1 & 8 & 1 \\
\hline
\end{tabular}




\begin{tabular}{|c|c|c|c|c|c|}
\hline \multirow[t]{2}{*}{ TR $\left(10^{9} / \mathrm{L}\right) 1^{\text {st }}$ sampling } & Female & 239.75 & 26.70 & 251.60 & 51.57 \\
\hline & Male & 261.80 & 31.07 & 264.00 & 52.69 \\
\hline \multirow[t]{2}{*}{ TR $\left(10^{9} / \mathrm{L}\right) 2^{\text {nd }}$ sampling } & Female & 259 & 38 & 269 & 50 \\
\hline & Male & 255 & 36 & 275 & 39 \\
\hline $\mathrm{K}$ (mmolL)_ $1^{\text {st }}$ sampling & Male & 4.4 & 0.2 & 4.0 & 0.2 \\
\hline $\mathrm{K}$ (mmolL)_2 $2^{\text {nd }}$ sampling & Male & 4.2 & 0.2 & 4.1 & 0.2 \\
\hline $\mathrm{Na}(\mu \mathrm{molL}) 1^{\text {st }}$ sampling & Male & 137 & 2 & 134 & 5 \\
\hline $\mathrm{Na}$ ( $\mu \mathrm{mol} \mathrm{L}) 2^{\text {nd }}$ sampling & Male & 137 & 2 & 136 & 5 \\
\hline $\mathrm{Cl}$ ( $\mu \mathrm{molL}) 1^{\text {st }}$ sampling & Male & 104 & 1 & 100 & 4 \\
\hline $\mathrm{Cl}$ ( $\mu$ molL)_2 $2^{\text {nd }}$ sampling & Male & 102 & 1 & 101 & 4 \\
\hline
\end{tabular}

\section{Figures}
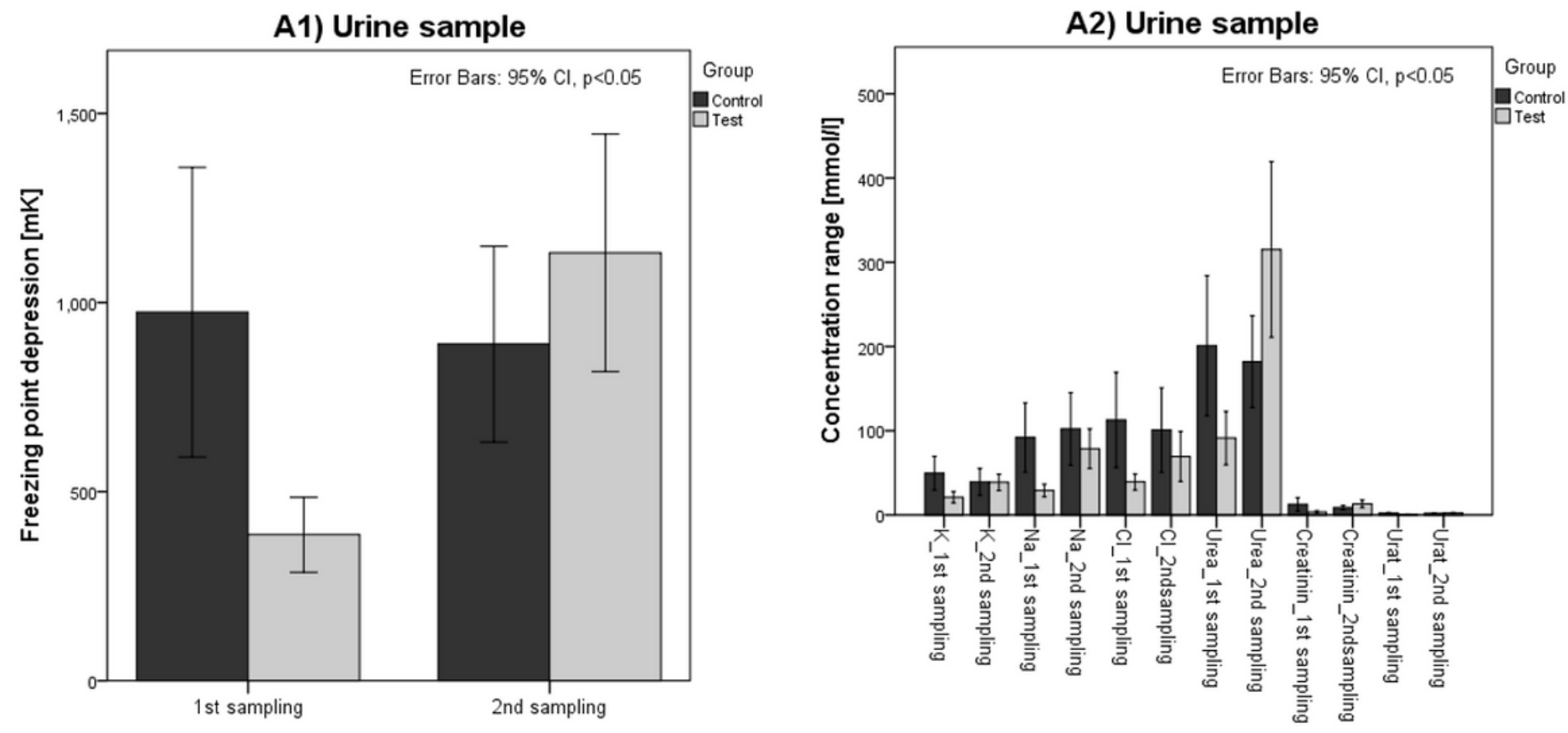

Figure 1

Differences between Test and Control group in Urine (A1, A2) and Blood (B) sample 